\title{
Article \\ Quantifying Climate Change and Ecological Responses within the Yangtze River Basin, China
}

\author{
Feiyan Chen ${ }^{1,2}$, Aiwen Lin ${ }^{1, *}$, Hongji Zhu ${ }^{1,3, *}$ and Jiqiang Niu ${ }^{2}$ \\ 1 School of Resource and Environmental Science, Wuhan University, Wuhan 430079, China; \\ feiyanchen16@126.com \\ 2 School of Geographic Sciences, Xinyang Normal University, Xinyang 464000, China; niujiqiang@xynu.edu.cn \\ 3 College of Resource Environment and Tourism, Hubei University of Arts and Science, \\ Xiangyang 441053, China \\ * Correspondence: awlin@whu.edu.cn (A.L.); zhuhongj@@whu.edu.cn (H.Z.)
}

Received: 4 July 2018; Accepted: 22 August 2018; Published: 25 August 2018

\begin{abstract}
The interactions between climate change and vegetation have a significant impact on the dynamics of the global carbon cycle. Based on the observed meteorological data from 1961 to 2013 and the temperature and precipitation data simulated by various climate models (simulations phase 5 of the Climate Model Intercomparison Project dataset), this paper analyzes the temperature and precipitation changes of the Yangtze River Basin (YRB) and finds that they are a similar trend, that is, the temperature presents a significant upward trend $\left(R^{2}=0.49, p<0.01\right)$, and the variation trend of precipitation is not significant $\left(R^{2}=0.01\right)$. Specifically, based on observed meteorological data, the annual mean temperature increased significantly and the area of increasing temperature accounted for $99.94 \%$ of the total region $(p<0.05)$; however, there was no significant change in annual precipitation. Ecological indicators (normalized difference vegetation index (NDVI); enhanced vegetation index (EVI); leaf area index (LAI); gross primary production (GPP); and net primary production (NPP)) of the YRB showed an increasing trend, and annual NDVI, annual EVI, LAI, annual total GPP and annual total NPP increased at respective rates of $0.002 \mathrm{yr}^{-1}, 0.001 \mathrm{yr}^{-1}, 0.07 \mathrm{~m}^{2} \mathrm{~m}^{-2} \mathrm{decade}^{-1}, 9 \mathrm{TgCyr}^{-1} \mathrm{yr}^{-1}$, and $6 \mathrm{TgCyr}^{-1} \mathrm{yr}^{-1}$, respectively. Correlation analysis between temperature/precipitation and NDVI/EVI/LAI/GPP/NPP was used to determine the relationships between climatic parameters and ecological indicators. Specifically, the temperature is significantly positively correlated with annual NDVI $\left(R^{2}=0.37, p<0.05\right)$, with annual mean LAI $\left(R^{2}=0.35, p<0.05\right)$ and with annual GPP $\left(R^{2}=0.37, p<0.05\right)$. In addition, there is a moderate positive correlation between mean EVI and mean growing season air temperature $\left(R^{2}=0.24\right)$; annual mean air temperature is a moderate positive correlation with annual NPP $\left(R^{2}=0.28\right)$. Our findings confirm that temperature is more closely related to ecological factors than precipitation over the YRB in these decades.
\end{abstract}

Keywords: climate change; ecological responses; spatiotemporal variability; Yangtze River Basin

\section{Introduction}

Climate change is indisputable and the interactions between climate change and terrestrial ecosystems have been enduring and accepted as one of the major issues in global change research. Climate variables, especially temperature and precipitation, are the vital factors that affect the development and ranges of ecosystems [1]. Global warming of $1.5^{\circ} \mathrm{C}$ above pre-industrial levels (Intergovernmental Panel on Climate Change (IPCC) website: http:/ / www.ipcc.ch/scripts/_session_ template.php?page=_44ipcc.htm), and the average temperature over the global land surface increased by $0.85^{\circ} \mathrm{C}$ from 1988 to 2011 (IPCC 5) which is consistent with the trend of climate change in China over the past 50 years, where the temperature has increased by up to $1.1{ }^{\circ} \mathrm{C}[2,3]$. The terrestrial 
ecosystem and the climate system are influential and interact with each other through processes such as energy, water vapor and material exchange [2]. Changes in climate greatly affect the distribution of vegetation and the carbon cycle of terrestrial ecosystems and, vice versa, the ecological responses of terrestrial ecosystems may substantially accelerate climate change [4-6]. As the main component of terrestrial ecosystems, vegetation is one of the main indicators of the effects of climate change on terrestrial ecosystems and plays a vital role in the dynamic balance of terrestrial carbon. Vegetation is also of great significance for both the greenhouse effect and mitigating the adverse effects of global warming [6-9].

The normalized vegetation index (NDVI), enhanced vegetation index (EVI), leaf area index (LAI), gross primary production (GPP) and net primary production (NPP) are key indicators for measuring vegetation, and to evaluate the effects of climate change on terrestrial ecosystems. Changes in NDVI and EVI and their causes have been analyzed and are an important part of research on terrestrial ecosystems $[10,11]$. LAI is the amount of leaf area per unit area and is a key structural parameter for measuring terrestrial vegetation and one of the primary inputs for calculating GPP and NPP [12]. Vegetation productivity is usually characterized by GPP or NPP [13]. GPP represents the amount of carbon that enters the vegetation from the atmosphere, and NPP is the total amount of carbon after subtracting autotrophic respiration (AR). They are not only key parameters for characterizing terrestrial ecological processes, indispensable for understanding the surface carbon cycle, but are also important ecological indicators for estimating the Earth's carrying capacity and for evaluating the sustainable development of terrestrial ecosystems.

Many studies have been carried out to explore the response of different regional ecosystems to climate change, found that the significant relationship between vegetation dynamics and precipitation often occurs in arid and semi-arid areas and areas with obvious climate differences in dry and wet seasons [14], temperature usually plays an important role of vegetation response in temperate or cool-temperate regions $[15,16]$. Across the Great Plains of central North America, NPP increased with decreasing temperature and increasing precipitation $[17,18]$, or grew with temperature $[19,20]$. A study of arid and semi-arid regions in China demonstrated that precipitation significantly positively affected GPP, NPP, and LAI, while the temperature was negatively correlated with NPP, and had no correlation with GPP [21]. Hao et al. [22] found that increases in temperature and precipitation in north-west China during the past three decades had a positive impact on annual mean LAI. In most parts of China, the temperature is the main climatic factor affecting the change of NPP. At the same time, in the arid and semi-arid regions of northern and north-west China, the interannual variation of NPP is mainly affected by the change of precipitation [23]. There are obvious spatial differences in the effects of climate change and human activities on vegetation dynamics [17]. To better understand climate change and its effects on ecological indicators, it is necessary to carry out research in different climatic zones.

The Yangtze River Basin (YRB) is an important climatic and economic zone in China, and mainly belongs to the subtropical monsoon region. Much research has been conducted on climate change across the YRB and its impact on ecological indicators. For example, in the semi-arid Tibetan Plateau region, increased NDVI is positively correlated with air temperature; however, an increase in temperature will ultimately inhibit vegetation growth due to reduced precipitation [24]. Zhou et al. [25] found that NDVI was mostly related to air temperature and not to precipitation in the upper reaches of the YRB. Zhang et al. [26] found that during the period of 2000-2009, the climate in the YRB exhibited a warming and drying trend, while GPP and NPP increased significantly, especially in the middle and lower reaches. Several researchers have also studied the impact of human activities on changes in ecological factors in the YRB [24,27]. However, given the ecological and economic importance of the region, arguably further research is needed on climate change across the YRB and its impact on multiple ecological factors.

Consequently, the main aims of the present study were: (1) to represent the spatiotemporal trends of climate change in the YRB from 1961-2013 using observed temperature and precipitation 
data and meteorological data derived from multiple model simulations (CMIP5); (2) to explore the corresponding variations in ecological indicators (NDVI, EVI, LAI, GPP, NPP); and (3) to analyze the relationships between climate change and ecological indicators. The results potentially provide an improved understanding of climate change and its impact on ecological indicators which may facilitate the protection of the ecological environment of the YRB, and aid in the formulation of policies for regional sustainable development in China and elsewhere.

\section{Materials and Methods}

\subsection{Study Area}

The study area of the YRB is based on the atlas published by the Yangtze River water conservancy commission in 1999 [28]. The YRB $\left(90^{\circ} 33^{\prime} \mathrm{E}-122^{\circ} 25^{\prime} \mathrm{E}\right.$ and $\left.24^{\circ} 30^{\prime} \mathrm{N}-35^{\circ} 45^{\prime} \mathrm{N}\right)$ is in the center of the Chinese mainland (Figure 1). The YRB is the third largest river basin in the world, with a total area of 1.8 million $\mathrm{km}^{2}$, representing $18.8 \%$ of China's land area. The current population of the YRB is 450 million, one-third of the total population of China [29]. Yichang (Hubei Province) and Hukou (Jiangxi Province) are the boundaries of the upper, middle and lower reaches of the YRB. The upstream source area is the Qinghai-Tibet Plateau, and the middle and lower reaches are Dongting Lake Plain, Jianghan Plain, Poyang Lake Plain, the Hilly Region of south-east China and the Yangtze River deltaic plain. The principal forms of land cover in the YRB are forest, arable, and grassland, representing more than $90 \%$ of the total area of the basin. The areas of water, construction land, and otherwise unused land are relatively small [30].

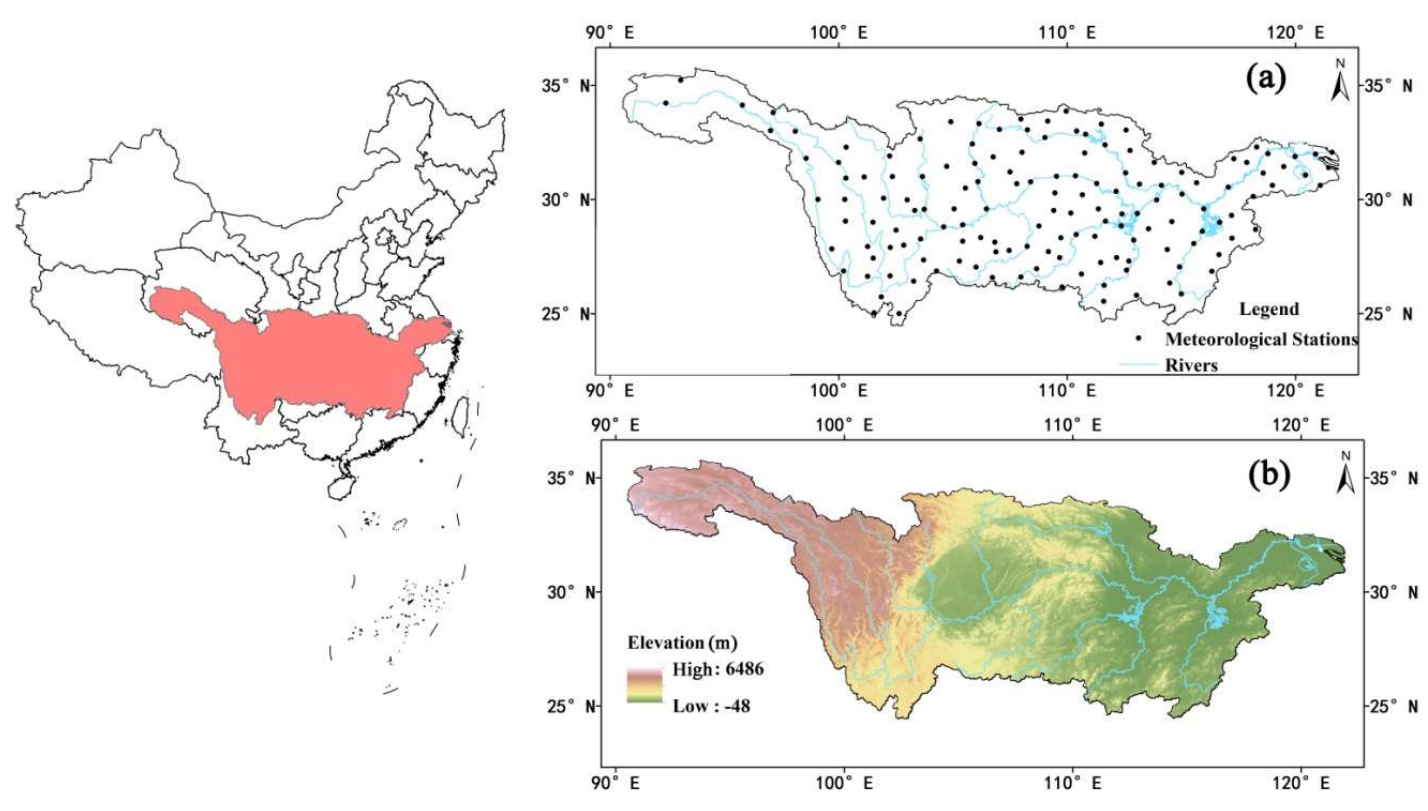

Figure 1. Location of the study area in China and (a) distribution of meteorological stations across the Yangtze River Basin (YRB); (b) topography of the YRB. The map projection system is World Geodetic System (WGS) 84.

\subsection{Data Sources and Processing}

\subsubsection{Climate Datasets}

The climate data sets used in this study were collected from the China Meteorological Data Service Center (CMDC, website: http:/ / data.cma.cn/). They are from 180 meteorological stations from across the YRB and cover the interval from 1961-2013. After removing stations with missing climatological and historical records (e.g., Banma, Guangshui, Folding and Pingwu), the number of stations decreased 
to 176; these stations provided high-quality and complete data sets for the study interval. We used spatial interpolation of the temperature and precipitation station to obtain a high-resolution climate change data set. The vegetation growing season in the YRB is from May to October [31].

2.2.2. Simulations of Temperature and Precipitation Data Using World Climate Research Programme (WCRP) Climate Model Intercomparison Project (CMIP5) Multiple Climate Models

The fifth phase of the Climate Model Intercomparison Project (CMIP5) was established by the World Climate Research Programme (WCRP) to support the Intergovernmental Panel on Climate Change (PICC's) assessment report. Although the CMIP5 model only provides analog output and has independent internal variability and initial conditions, and the observed synoptic model was different, the trends of variation between observed and simulated climate data provide useful information for achieving a better understanding of climate changes [32,33].

The data used in this study are from the Program for Climate Model Diagnosis and Intercomparison (PCMDI) database (https://pcmdi9.1lnl.gov/search/cmip5/). It comprises temperature and precipitation data from six models (CanESM2, CCSM4, INM-CM4, MIROC-ESM-CHEM, MPI-ESM-LR and MRI-CGCM3. See Table 1) of the CMIP5 model base for the YRB during 1961-2013 [21,32,34]. Based on the monthly temperature and precipitation data obtained from the six models, annual precipitation and temperature data were calculated and compared with the site meteorological data to examine the climatic trend of the YRB during 1961-2013 (Table 1).

Table 1. Descriptions of the selected climate models from the World Climate Research Programme (WCRP) Climate Model Intercomparison Project (CMIP5) models.

\begin{tabular}{ccc}
\hline Models & Resolution [lat $\left({ }^{\circ} \mathbf{N}\right) \times \operatorname{lon}\left({ }^{\circ}\right.$ E] & Modeling Center/Group \\
\hline CanESM2 & $64 \times 128$ & Canadian Centre for Climate Modeling and Analysis \\
CCSM4 & $192 \times 288$ & National Center for Atmospheric Research, United States \\
INM-CM4 & $120 \times 180$ & Institute for Numerical Mathematics, Russia \\
MIROC-ESM-CHEM & $64 \times 128$ & Model for Interdisciplinary Research on Climate, Japan \\
MPI-ESM-LR & $96 \times 192$ & Max Planck Institute for Meteorology, Germany \\
MRI-CGCM3 & $160 \times 320$ & Meteorological Research Institute, Japan \\
\hline
\end{tabular}

2.2.3. Moderate Resolution Imaging Spectroradiometer (MODIS) Normalized Difference Vegetation Index/Enhanced Vegetation Index (NDVI/EVI)

The Moderate Resolution Imaging Spectroradiometer (MODIS) normalized difference vegetation index product, MODIS 13A1, is a global vegetation dataset with a 500-m spatial resolution, and a 16-day composite temporal resolution (http:/ /ladsweb.nascom.nasa.gov/data/search.html). The products from January 2001 to December 2013 were used in this study. The maximum value composites (MVC) were used to synthesize each 16-day data interval into monthly data, annual NDVI and annual EVI is averaged by the monthly NDVI and EVI data. The NDVI and EVI during the growing season (May-October) in the YRB during 2001-2013 were produced based on the average of the 6-month NDVI and EVI data.

2.2.4. Advanced Very High-Resolution Radiometer (AVHRR) at Boston University (BU) generated the Leaf Area Index (LAI)

We used the third-generation Global Inventory Modelling and Mapping Studies (GIMMS) normalized difference vegetation index (NDVI3g) from Advanced Very High-Resolution Radiometer (AVHRR) sensor products. These datasets have the following properties: temporal resolution of 15 days, and the spatial resolution of 1/12 for the period from 1982-2011 [35]. Monthly data were synthesized using the maximum synthesis method (MAC) from the original datasets. 


\subsubsection{MODIS Gross Primary Production/Net Primary Production (GPP/NPP)}

The GPP/NPP datasets used in our research are from MODIS vegetation index products, which are obtained from the National Aeronautics and Space Administration (NASA) Earth observation system (http:/ /ladsweb.nascom.nasa.gov/data/search.html). Collection 5 MOD17A3 products, these datasets have the following properties which were selected for study: $1 \mathrm{~km}$ spatial resolution, 8-day temporal resolution, from 2000 to 2010 (Table 2).

Table 2. Description of the multi-source data used in this study.

\begin{tabular}{|c|c|c|c|}
\hline Data Category & Data Description & Interval & Source \\
\hline \multirow{2}{*}{ Climate data } & Daily mean temperature & 1961-2013 & \multirow{2}{*}{$\begin{array}{c}\text { China Meteorological Data Service Center (CMDC) } \\
\text { (http:// data.cma.cn/) }\end{array}$} \\
\hline & Daily precipitation & 1961-2013 & \\
\hline \multirow{3}{*}{ Ecological indicator } & $\begin{array}{c}\text { Normalized Difference } \\
\text { Vegetation Index/Enhanced } \\
\text { Vegetation Index } \\
\text { (NDVI/EVI) }\end{array}$ & 2001-2013 & $\begin{array}{l}\text { Moderate Resolution Imaging Spectroradiometer (MODIS) } \\
\text { 13A1 product } \\
\text { (http://ladsweb.nascom.nasa.gov/data/search.html) }\end{array}$ \\
\hline & Leaf Area Index (LAI) & 1982-2011 & $\begin{array}{l}\text { Advanced Very High-Resolution Radiometer (AVHRR) at } \\
\text { Boston University (BU) generated the Leaf Area Index } \\
\text { (LAI) datasets (http:// sites.bu.edu/cliveg/datacodes) }\end{array}$ \\
\hline & $\begin{array}{l}\text { Gross Primary } \\
\text { Production/Net Primary } \\
\text { Production (GPP/NPP) }\end{array}$ & 2000-2010 & $\begin{array}{c}\text { MODIS 17A3 product } \\
\text { (http:/ /ladsweb.nascom.nasa.gov/data/search.html) }\end{array}$ \\
\hline
\end{tabular}

\subsection{Methodology}

To facilitate assessment of climate trends in the region, it is necessary to interpolate temperature and precipitation data to produce spatially continuous data. Spatial interpolation methods such as the Thiessen polygon [36], radial basis functions (RBF) [37], Kriging interpolation [38] and inverse distance weighting (IDW) [39] can be interpolated. Kriging is an estimation of optimal, linear and unbiased interpolation of spatial distribution data, which is divided into ordinary kriging and co-kriging, etc. Compared to other methods, co-kriging [40] not only takes the spatial correlation of the known data points but the elevation factor as well. Therefore, we used this method for the spatial interpolation of the atmospheric and rainfall data by choosing the elevation of each meteorological station as the covariable and implementing repeated exploratory spatial data analysis, cross validation, error analysis, and parameter modification, to get the better spatial distribution map of them over the YRB.

Regression and correlation are the most commonly used analytical methods [41]. We used linear regression analysis to analyze the trends of the meteorological factors and ecological indicators at two scales: for the whole basin and for the grid unit [42]. The rate of change of the climatic parameters (e.g., temperature and precipitation) and the ecological indicators (e.g., NDVI, EVI, LAI, GPP, NPP) were calculated using Equation (1) [43],

$$
S=\frac{n \times \sum_{i=1}^{n}(T i \times E i)-\left(\sum_{i=1}^{n} T i\right)\left(\sum_{i=1}^{n} E i\right)}{n \times \sum_{i=1}^{n} T i^{2}-\left(\sum_{i=1}^{n} T i\right)^{2}}
$$

Here, $S$ is the slope of the trend line of the climatic factors and the ecological indicators; $T_{i}$ is the time label; $n$ is the number of years, and $E_{i}$ is the value of the climatic factor or ecological indicator for the $i$ year. $S$ describes the trend in the climatic factors or the ecological indicators. If $S>0$, the variation of the dependent variable exhibits an increasing trend, whereas if $S<0$, the variation of the dependent variable exhibits a decreasing trend. The linear variation trend of climatic factors and ecological factors was calculated by least squares linear fitting using the time series data for each pixel. A program was implemented using MATLAB to calculate the slope and the significance of the regression of air temperature/precipitation and NDVI/EVI/LAI/GPP/NPP for each pixel. 
Pearson correlation coefficients were calculated between air temperature/precipitation and NDVI/EVI/LAI/GPP/NPP. The significance of the correlation coefficients was assessed at the 0.01 and 0.05 levels.

\section{Results}

\subsection{Trends of the Climatic Parameters in the Yangtze River Basin (YRB) during 1961-2013}

Figure 2 shows the annual average temperature variation trend of temperature and precipitation in the YRB. The annual mean air temperature was $12.79{ }^{\circ} \mathrm{C}$ during $1961-2013$, with a maximum of $13.82{ }^{\circ} \mathrm{C}$ in 2006 and a minimum of $12.15^{\circ} \mathrm{C}$ in 1984 . The annual mean temperature shows a significant upward trend and the correlation significant is at 0.01 level (Figure 2a); it increased by $0.82{ }^{\circ} \mathrm{C}$ during 1961-2013, a rate of $0.016^{\circ} \mathrm{C}$ decade ${ }^{-1}$, and this rate increased to $0.42{ }^{\circ} \mathrm{C}$ decade ${ }^{-1}$ during the 1980 s. The decadal mean air temperature during 1961-2013 increased: $12.54{ }^{\circ} \mathrm{C}(1961-1970)$, as follows: $12.54{ }^{\circ} \mathrm{C}(1971-1980), 12.51{ }^{\circ} \mathrm{C}(1981-1990), 12.85^{\circ} \mathrm{C}(1991-2000)$, and $13.40{ }^{\circ} \mathrm{C}(2001-2010)$.
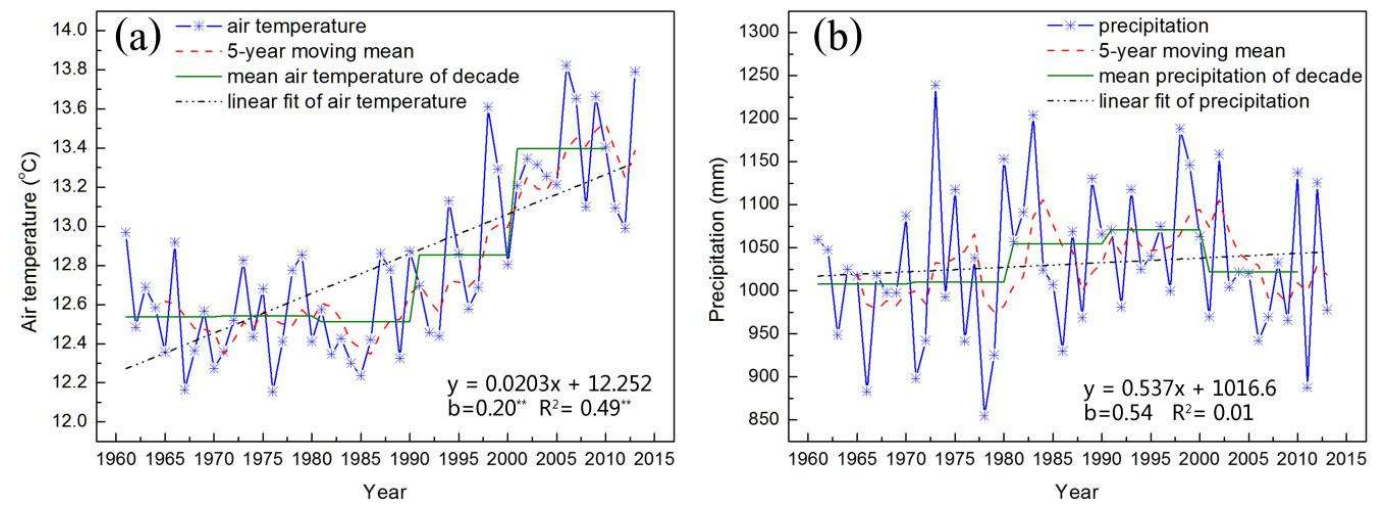

Figure 2. Temporal trends in annual mean air temperature and precipitation in the YRB during 1961-2013. (a) Temporal trends in average air temperature; (b) temporal trends in precipitation. $b$ is the regression coefficient. Significance level: ${ }^{* *}$ means the significant of the $99 \%$ confidence interval, $p<0.01,{ }^{*}$ means the significant of the $95 \%$ confidence interval, $p<0.05$.

However, there is no significant trend in annual mean precipitation (Figure 2b). The annual mean precipitation during 1961-2013 fluctuates $1031.15 \mathrm{~mm}$, with a maximum of $1239 \mathrm{~mm}$ in 1973 and a minimum of $854.68 \mathrm{~mm}$ in 1978. The decadal mean precipitation varied over the last five decades, as follows: $1008 \mathrm{~mm}$ (1961-1970), $1055 \mathrm{~mm}$ (1971-1980), $1071 \mathrm{~mm}$ (1981-1990), $1022 \mathrm{~mm}$ (1991-2000), and $1148 \mathrm{~mm}(2001-2010)$.

The seasonal mean value of observed air temperature during 1961-2013 shows a similar spatial distribution pattern in every season (Figure 3), with lower air temperatures in the high-altitude areas in the upper reaches of the YRB [44].

The spatial patterns of the linear trends in air temperature are illustrated in Figure 4. Spring temperatures increased more rapidly mostly in the lower altitude areas of the middle and lower reaches of the YRB (MLYRB). Summer and winter temperatures have similar distributions, where the temperature is increasing rapidly are mainly in the source region of the Yangtze River (SRYR), in eastern Tibet and in the Yunnan Plateau. The areas of rapid temperature increase in autumn are chiefly distributed across the higher altitude areas of the YRB and in the densely populated areas of the Yangtze River Delta (YRD). 


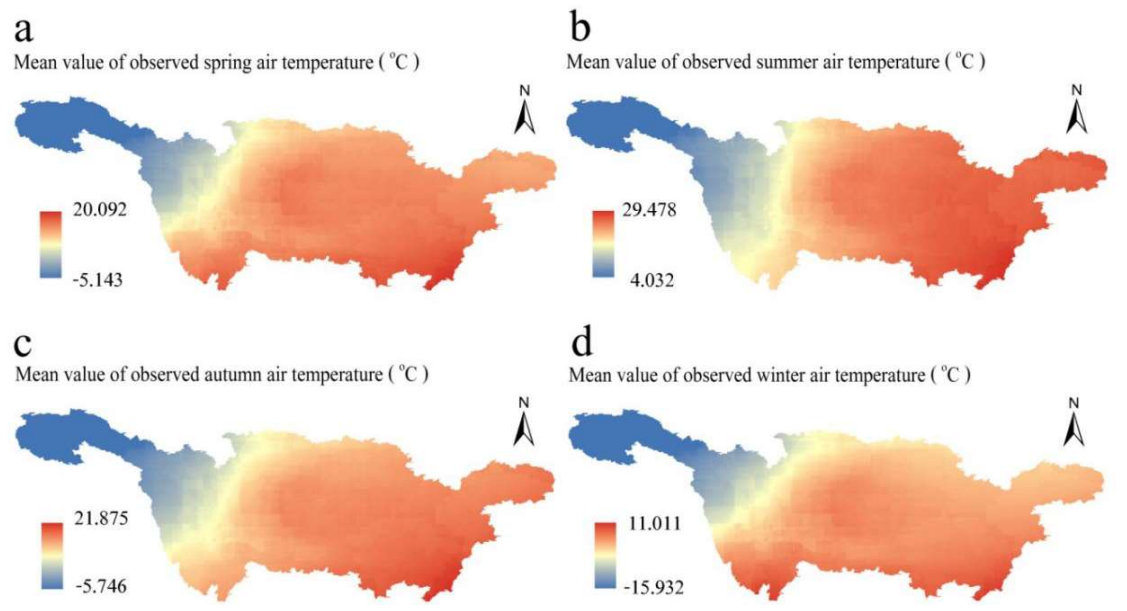

Figure 3. Spatial distribution of (a) the mean value of observed spring air temperature, (b) the mean value of observed summer air temperature, (c) the mean value of observed autumn air temperature and (d) the mean value of observed winter air temperature in the YRB during 1961-2013.



Figure 4. Spatial distribution of (a) the linear trends in observed spring air temperature, (b) the linear trends in observed summer air temperature, (c) the linear trends in observed autumn air temperature and (d) the linear trends in observed winter air temperature for the YRB during 1961-2013.

The spatial distributions of the seasonal mean value of observed precipitation during 1961-2013 exhibit a differentiated spatial pattern (Figure 5). Precipitation in the SRYR during the years was relatively low compared to other areas in the YRB. The areas with more precipitation in spring are mainly located in the lower elevations of the hilly regions of south-eastern China reflect the influence of the monsoon (Figure 5a). The regions with less precipitation in summer are mostly distributed across the SRYR and in the Hanzhong Basin (Figure $5 b$ ). The areas with increased autumn precipitation are principally distributed within the Sichuan Basin (Figure 5c), and the areas with increased winter precipitation are mainly concentrated in the south-eastern region of the Xiang-Gan Mountains (Figure 5d). 
a

Mean value of observed spring precipitation ( $\mathrm{mm}$ )

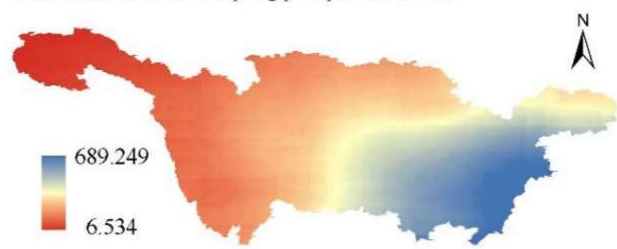

$\mathrm{c}$

Mean value of observed autumn precipitation ( $\mathrm{mm}$ )

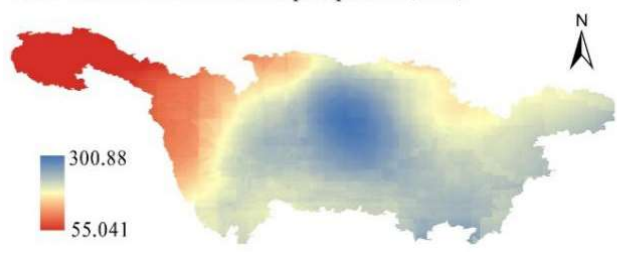

b

Mean value of observed summer precipitation ( $\mathrm{mm}$ )

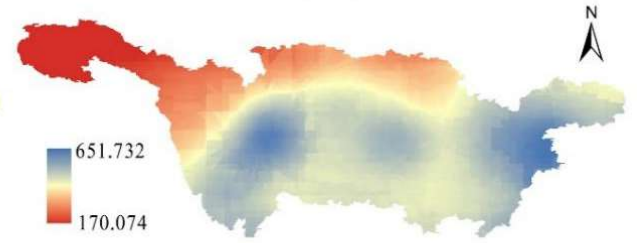

d

Mean value of observed winter precipitation ( $\mathrm{mm}$ )

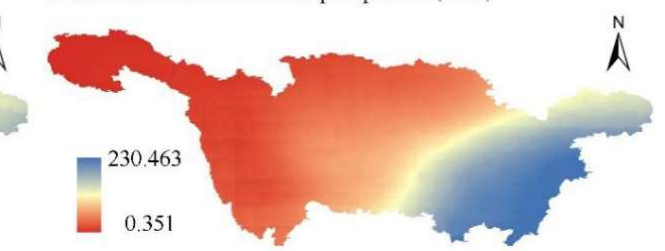

Figure 5. Spatial distribution of (a) the mean value of observed spring precipitation, (b) the mean value of observed summer precipitation, (c) the mean value of observed autumn precipitation and (d) the mean value of observed winter precipitation for the YRB during 1961-2013.

The areas of decreased spring precipitation are principally distributed across the MLYRB (Figure 6a). The areas with increased summer precipitation are concentrated in the low altitude regions of the YRD, and those with decreasing trends are mostly concentrated in the Yun-Gui plateau region (Figure $6 b$ ). Areas with increased autumn precipitation are chiefly concentrated in the SRYR and in some parts of the southern hills, while there is a decreasing trend in other areas of the YRB (Figure 6c). In winter, most of the regions of the YRB exhibit a decreasing precipitation trend; however, the MLYRB and the hilly regions of south-eastern China exhibit an increasing precipitation trend (Figure 6d).

a Slope of the linear fitting of observed spring precipitation

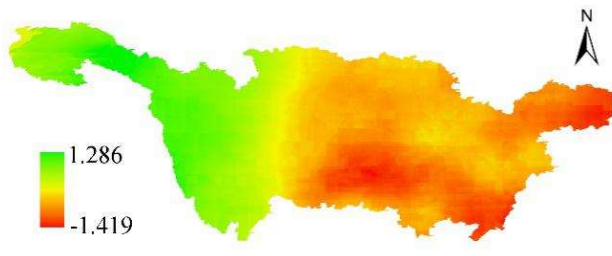

C

Slope of the linear fitting of observed autumn precipitation

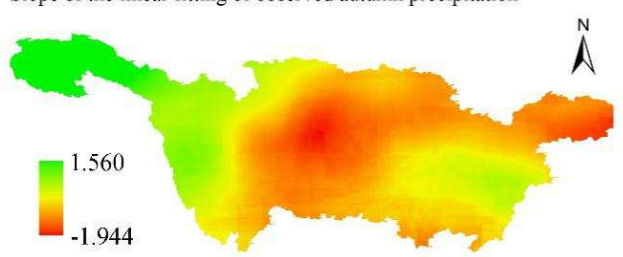

b Slope of the linear fitting of observed summer precipitation



d

Slope of the linear fitting of observed winter precipitation

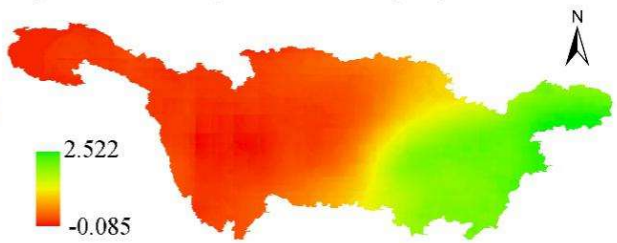

Figure 6. Spatial distribution of (a) the linear trends in observed spring precipitation, (b) the linear trends in observed summer precipitation, (c) the linear trends in observed autumn precipitation and (d) the linear trends in observed winter precipitation for the YRB during1961-2013.

The areas with relatively low observed annual air temperature in the YRB from 1961 to 2013 are mostly located in high-altitude areas such as the SRYR, eastern Tibet and western Sichuan, and the areas with higher values are chiefly in the low-elevation areas in the MLYRB (Figure 7a). Areas with 
low mean values of observed precipitation are mainly in the SRYR, the western part of Sichuan Basin and the eastern part of Hanzhong Basin; and the areas with high values of observed precipitation are principally located in the southeastern part of the Xiang-Gan Mountains (Figure 7b).

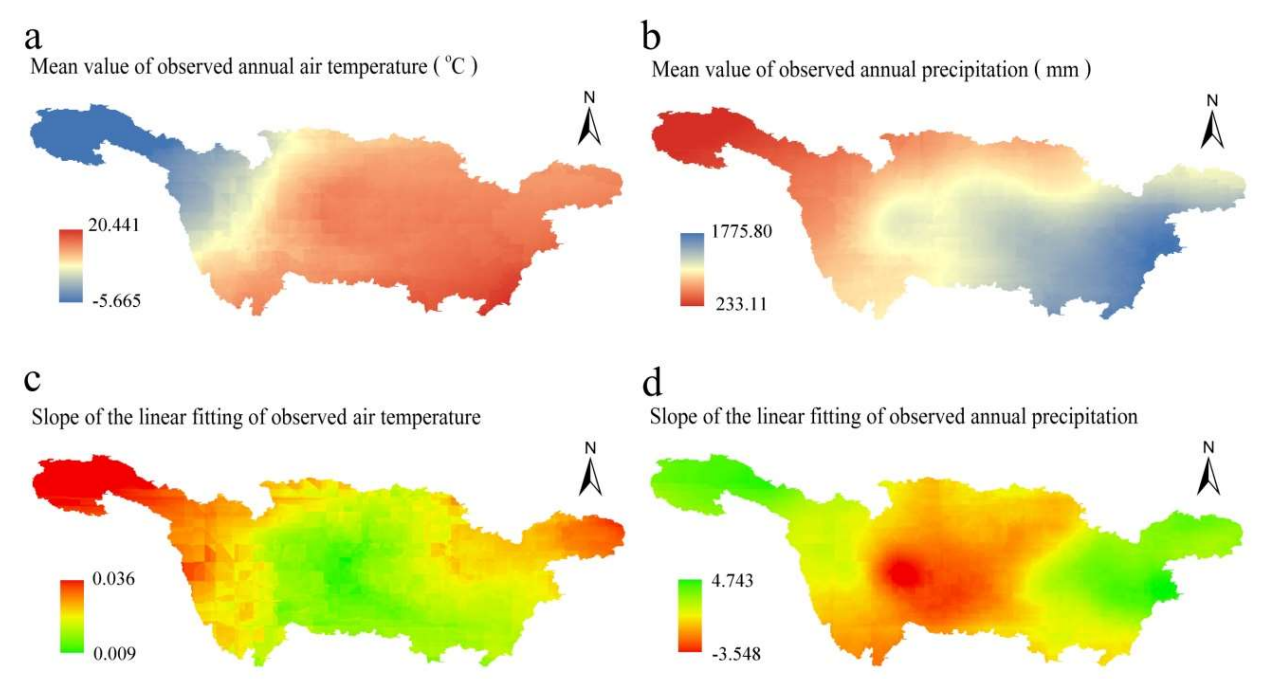

Figure 7. Spatial distribution of (a) mean observed annual air temperature, (b) mean of observed annual precipitation, (c) linear trends in observed annual temperature and (d) observed annual precipitation over the YRB during 1961-2013.

Temperatures in the YRB increased during 1961-2013. The regions of increased temperature are mainly distributed in the SRYR and in urban areas of the YRD (Figure 7c). The areas with increased precipitation are mainly in the SRYR and the eastern parts of the MLYRB; and the areas with decreased precipitation are mostly scattered in the north-eastern Yunnan Plateau, the western part of the Guizhou Plateau, and the south-western part of Sichuan Basin (Figure 7d).

The modeled mean annual temperatures are illustrated in Figure 8a. The values for CanEMS2 $\left(9.1^{\circ} \mathrm{C}\right)$, MPI-ESM-LR $\left(8.77^{\circ} \mathrm{C}\right)$ and MIROC-ESM-CHEM $\left(7.5^{\circ} \mathrm{C}\right)$ are higher than those for CCSM4 $\left(7.27^{\circ} \mathrm{C}\right)$, MIR-CGCM3 $\left(6.27^{\circ} \mathrm{C}\right)$, and INM-CM4 $\left(4.62^{\circ} \mathrm{C}\right)$. Annual temperature exhibits increasing trends and all are significant at the 99\% confidence level. As shown in Figure 8b, increasing trends of annual precipitation are shown by MIR-OC-ESM-CHEM, INM-CM4, and CanESM2 and decreasing trends are shown by MRI-CGCM3, MPI-ESM-LR and CCSM4; however, none of these results are statistically significant.

We used a non-parametric method (the Kolmogorov-Smirnov (KS) test) to compare the observed annual temperature and precipitation data with the results from the various models (Figure 9). The KS compares the distribution of $f(x)$ with the theoretical distribution $g(x)$ and two observation values. $\mathrm{H}_{0}$ assumes that the two data distributions are consistent or that the data conforms to the theoretical distribution [45]. The results for the observed data and for the data from the meteorological stations are significant at the 0.01 level, indicating that although they are different data distributions, the annual air temperature and annual precipitation increase significantly in both cases (Figure 8). 

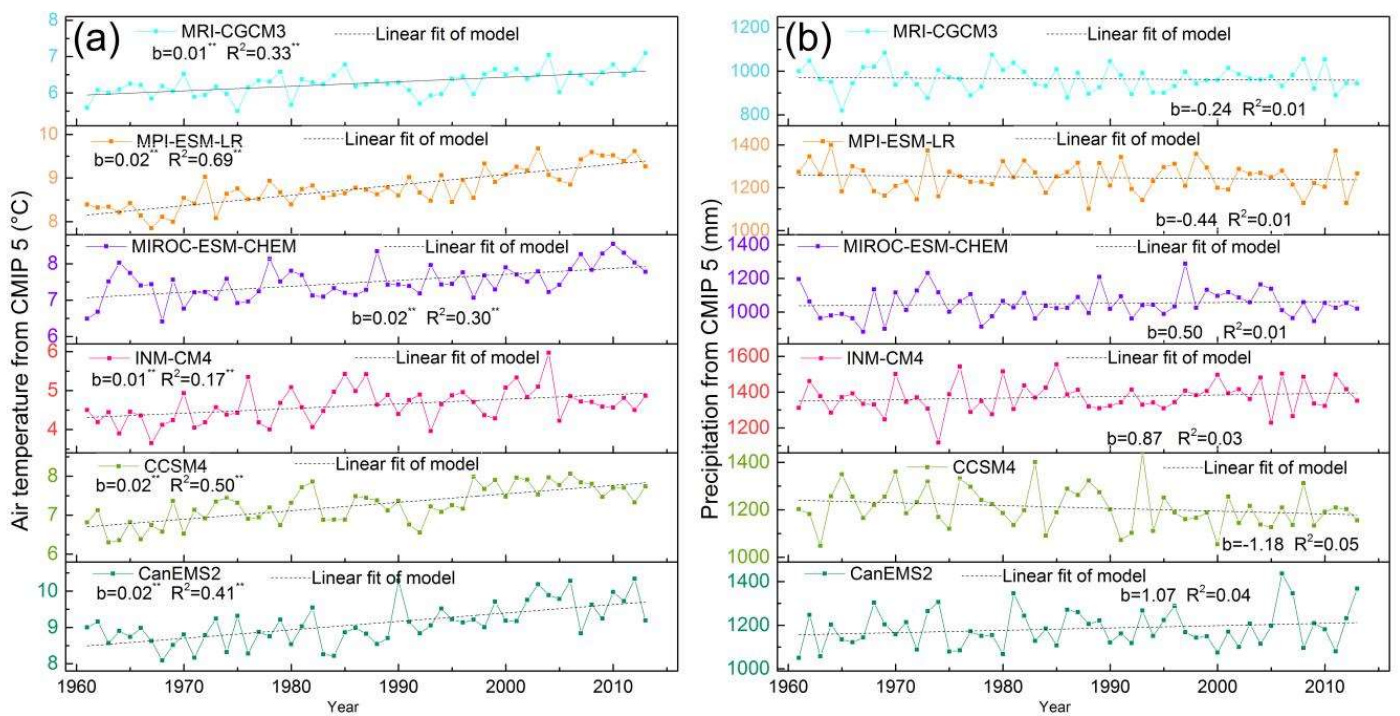

Figure 8. Modeled temporal variations of climate change over the YRB during 1961-2013. (a) Mean annual temperature, (b) mean annual precipitation. The data are based on multiple model simulations from the WCRP CMIP5. $b$ : regression coefficient, Significance level: ${ }^{* *}$ means the significant of the $99 \%$ confidence interval, $p<0.01,{ }^{*}$ means the significant of the $95 \%$ confidence interval, $p<0.05$.

a

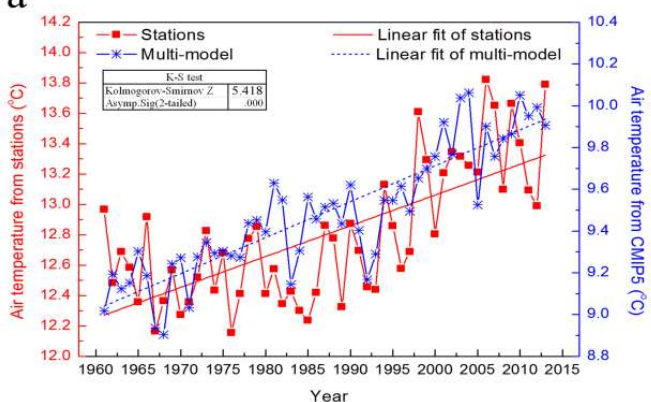

b

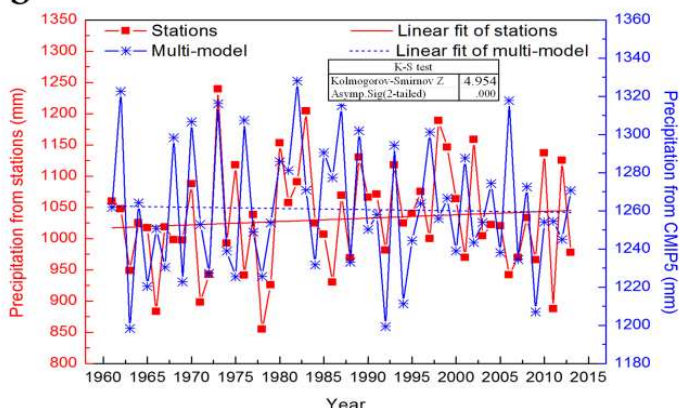

Year

Figure 9. Comparison of trends in (a) annual precipitation and (b) mean annual air temperature of meteorological stations and CMIP5 model outputs for the YRB during 1961 to 2013 (A non-parametric test was used).

\subsection{Trends in Ecological Indicators in the $Y R B$}

The annual mean NDVI and EVI values for the YRB during 2001-2013, which are produced from the annual 500-m data in proved NDVI and EVI products (MOD 13A1), are illustrated in Figure 10. The annual mean NDVI is 0.565 , with a maximum of 0.577 in 2007 ( 0.012 above the mean) and a minimum of 0.548 in 2001 ( 0.017 below the mean); the annual mean NDVI increased by 0.017 in 2001 (0.548) to $2013(0.577)$, a rate of $0.002 \mathrm{yr}^{-1}$. The annual mean EVI is 0.31 , with a maximum of $0.321 \mathrm{in}$ 2007 ( 0.011 above the mean) and a minimum of 0.298 in 2001 ( 0.013 below the mean); the annual mean EVI increased by 0.016 in 2001 (0.298) to 2013 (0.313), a rate of $0.001 \mathrm{yr}^{-1}$ (Figure 10). 


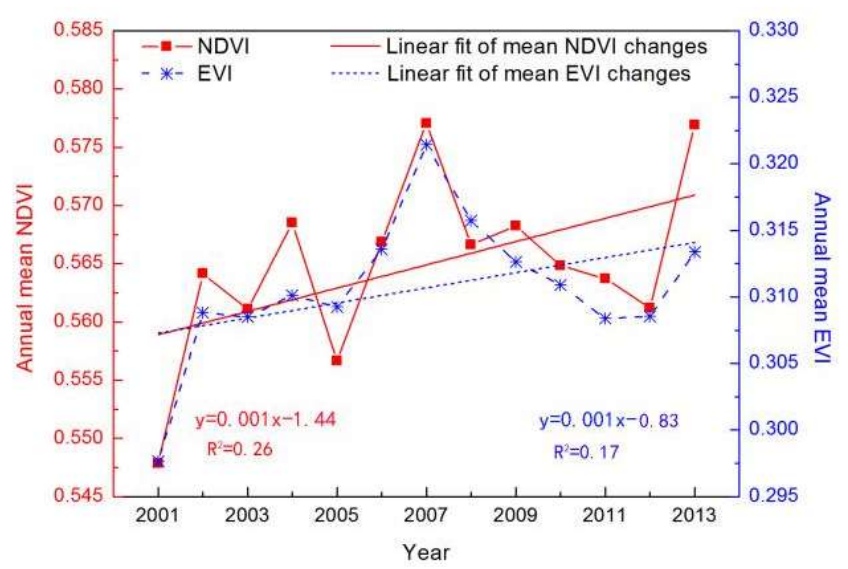

Figure 10. Inter-annual variations of annual mean NDVI and EVI over the YRB during 2001-2013.

Figure 11 illustrates the spatial distribution of the mean value of NDVI in the growing season (Figure 11a), the mean value of EVI in the growing season (Figure 11c), the mean value of annual NDVI (Figure 11b), and the mean value of annual EVI (Figure 11d), for the YRB from 2001-2013. The mean values of both annual NDVI and EVI, including the Han River Basin, the Wu River Basin, most of Jiangxi and a small part of Zhejiang Province, exhibit higher values, and the Jinsha River Basin and the urban areas of the MLYRB exhibit lower values.

a



C

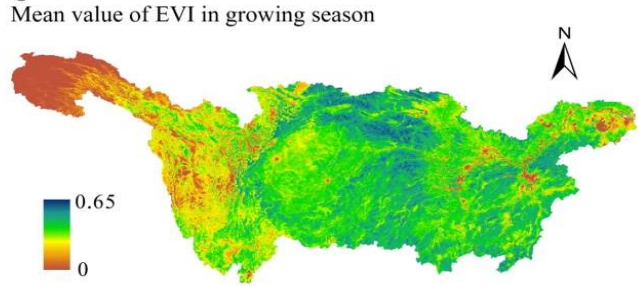

b

Mean value of annual NDVI

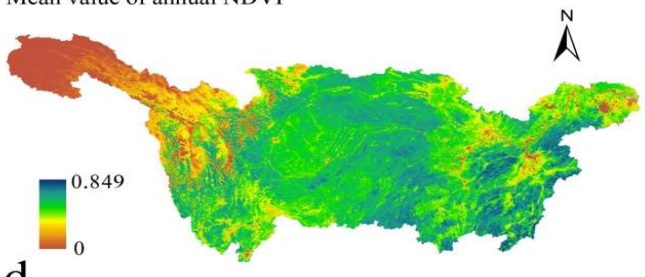

$\mathrm{d}$

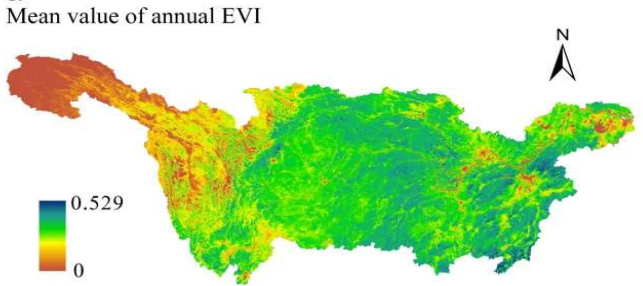

Figure 11. Spatial distribution of (a) mean growing season NDVI, (b) mean annual NDVI, (c) mean growing season EVI, (d) mean annual EVI in the YRB during 2001-2013.

In general, the annual NDVI and EVI increased from 2001 to 2013, and these increases are consistent with the changes in the mean values of NDVI and EVI in the growing season, which are illustrated in Figure 12. The results are summarized in Table 3 and they show that the annual NDVI and EVI exhibit increasing trends, accounting for $65.29 \%$ and $60.23 \%$ of the YRB, respectively. As shown in Figure 12, the increasing trend occurred mainly in the central and north-eastern parts of Hanzhong Basin, in the Jialing and Wujiang River basins, and in the north-eastern part of Sichuan Basin. The areas with a decreasing trend are chiefly distributed in arid and semi-arid areas of the SRYR and in the urbanized areas of the MLYRB. 
a

Slope of the linear fitting of mean NDVI changes in growing season

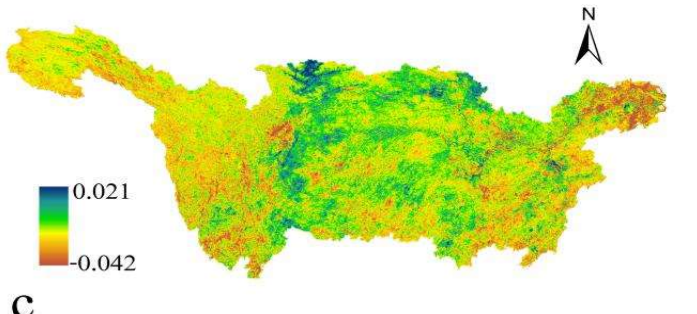

Slope of the linear fitting of mean EVI changes in growing season

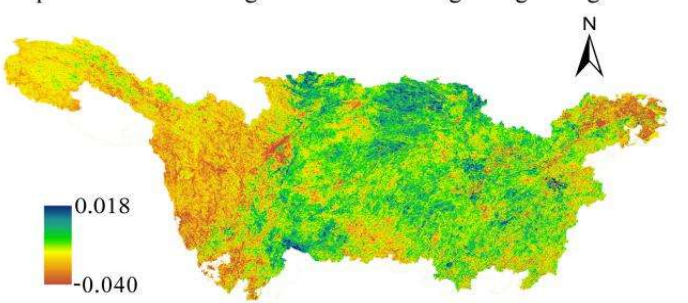

b

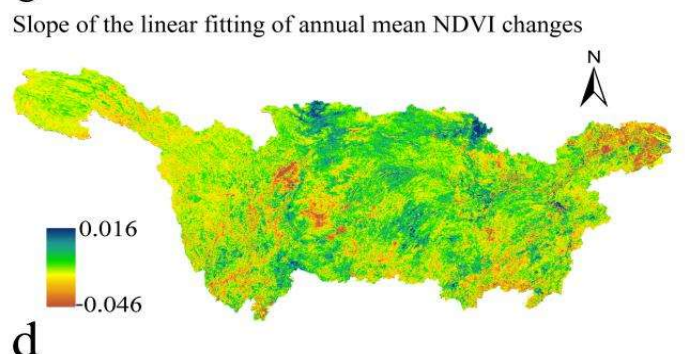

$\mathrm{d}$

Slope of the linear fitting of annual mean EVI changes



Figure 12. Spatial distribution of linear trends in (a) mean growing season NDVI, (b) mean annual NDVI, (c) mean growing season EVI, and (d) mean annual EVI in the YRB during 2001-2013.

Table 3. Results of trend analysis of meteorological parameters and ecological indicators on the pixel scale.

\begin{tabular}{ccccccc}
\hline \multirow{2}{*}{ Variables } & \multicolumn{3}{c}{ Increasing (slope $>\mathbf{0})$} & \multicolumn{2}{c}{ Decreasing $($ slope $<\mathbf{0 )}$} \\
\cline { 2 - 7 } & Total & $\boldsymbol{p}<\mathbf{0 . 0 1}$ & $\boldsymbol{p}<\mathbf{0 . 0 5}$ & Total & $\boldsymbol{p}<\mathbf{0 . 0 1}$ & $\boldsymbol{p}<\mathbf{0 . 0 5}$ \\
\hline Air temperature & 100.00 & 0.06 & 99.94 & - & - & - \\
Precipitation & 58.66 & 3.72 & 11.59 & 41.34 & 3.80 & 4.24 \\
Annualmean NDVI & 65.29 & 9.08 & 13.15 & 34.71 & 2.72 & 2.97 \\
Annualmean EVI & 60.23 & 9.04 & 10.15 & 39.77 & 3.71 & 4.08 \\
Annualmean LAI & 83.35 & 14.05 & 34.08 & 16.65 & 1.05 & 1.07 \\
Annual GPP & 70.04 & 4.20 & 2.79 & 29.96 & 0.27 & 0.37 \\
Annual NPP & 72.77 & 3.42 & 2.38 & 27.23 & 0.16 & 0.53 \\
\hline
\end{tabular}

During the last 30 years, the annual mean LAI increased significantly, from $1.57 \mathrm{~m}^{2} \mathrm{~m}^{-2}$ in 1982 to $1.79 \mathrm{~m}^{2} \mathrm{~m}^{-2}$ in 2011(a rate of $0.07 \mathrm{~m}^{2} \mathrm{~m}^{-2}$ per decade) across the YRB (Figure 13). The spatial distribution of growing season LAI is similar to that of annual mean LAI in the YRB; the values are higher in the foothills of the Tibetan Plateau, the Han River Basin and the Poyang Lake Basin; and the values are lower in the MLYRB and in the densely urbanized area of Taihu Basin (Figure 14).

Spatially, for $83.35 \%$ of the pixels, the annual mean LAI exhibits an increasing trend during 1982-2011 (Table 3). The mean LAI in the growing season and the annual mean LAI increased significantly in the basins of the Jialing and Wujiang Rivers and in the Dongting and Poyang lakes' basins. Areas of reduced values are mainly concentrated in MLYRB and in the Taihu Basin (Figure 14).

The results of linear regression analysis reveal a slight increasing trend in annual total GPP for the entire YRB, with an annual rate of change of up to $9 \mathrm{TgCyr}^{-1} \mathrm{yr}^{-1}$. These results indicate that mean annual total GPP was $1905 \mathrm{TgCyr}^{-1}$, with a maximum of $1954 \mathrm{TgCyr}^{-1}$ in $2004\left(49 \mathrm{TgCyr}^{-1}\right.$ above the mean) and a minimum of $1775 \mathrm{TgCyr}^{-1}$ in 2000 (130 $\mathrm{TgCyr}^{-1}$ below the mean). Annual total GPP increased from $1775 \mathrm{TgCyr}^{-1}$ in 2000 to $1869 \mathrm{TgCyr}^{-1}$ in 2010 (Figure 15). 

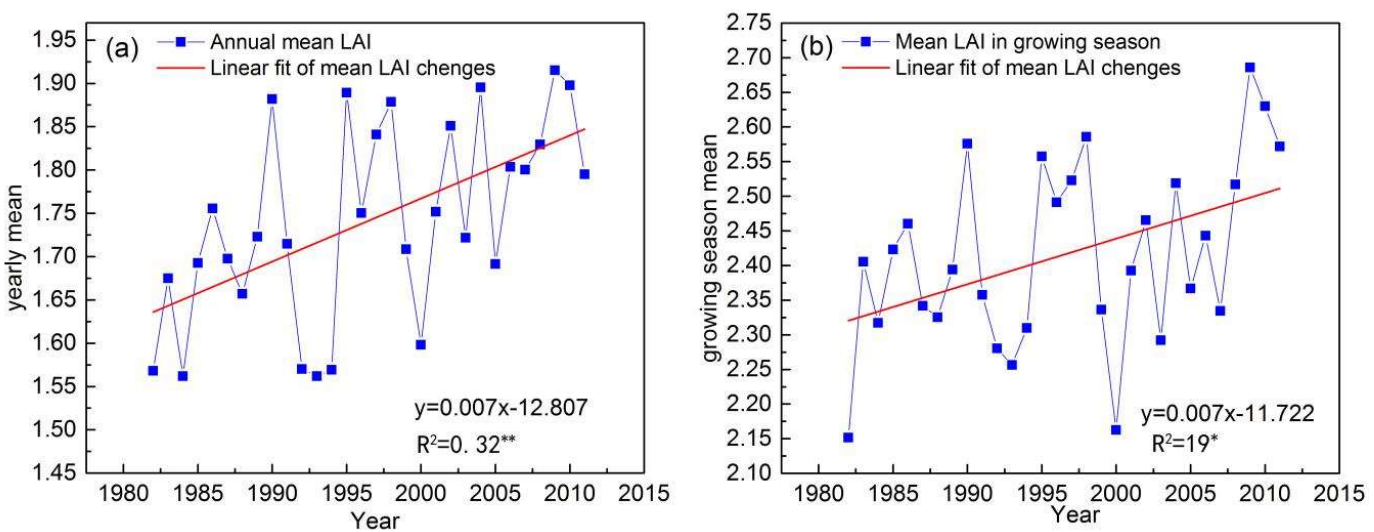

Figure 13. Temporal trends in (a) annual mean LAI and (b) mean LAI in growing season in the YRB during 1982-2011.

a

Mean value of $\mathrm{LAI}$ in growing season $\left(\mathrm{m}^{2} / \mathrm{m}^{2}\right)$



C Slope of the linear fitting of mean LAI changes in growing season

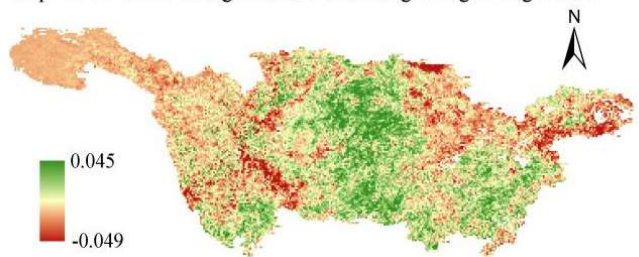

b

Mean value of annual $\mathrm{LAI}\left(\mathrm{m}^{2} / \mathrm{m}^{2}\right)$

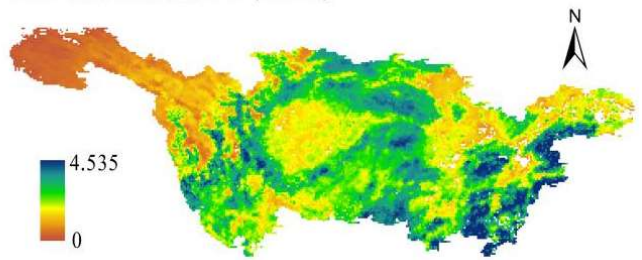

d

Slope of the linear fitting of annual mean LAI changes

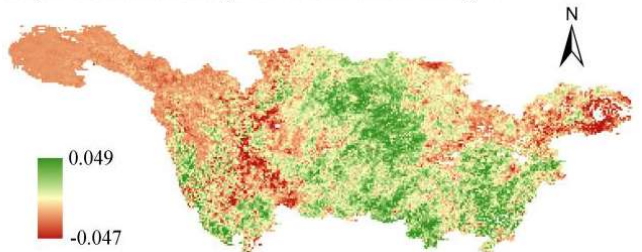

Figure 14. Spatial distribution of (a) mean value of LAI in growing season; (b) mean value of annual LAI; (c) linear fitting of mean LAI changes in growing season; (d) linear fitting of annual mean LAI changes in the YRB during 1982-2011.

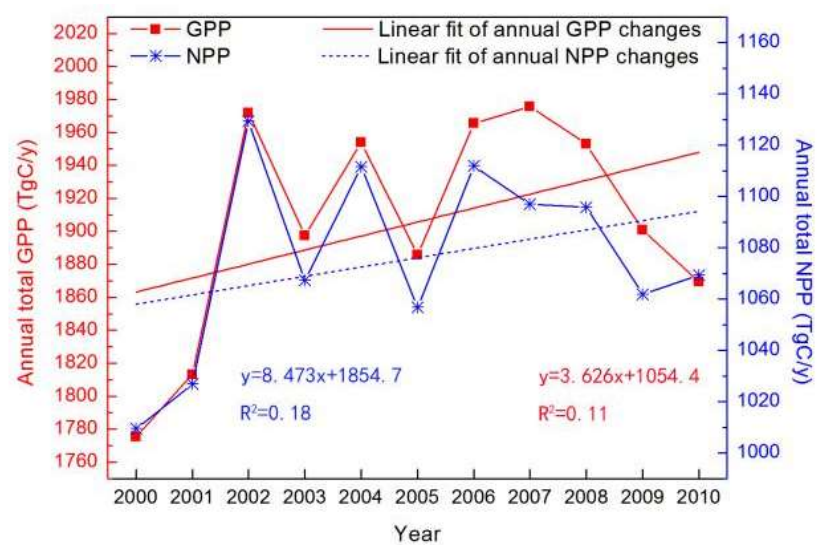

Figure 15. Trends of annual total GPP and NPP in the YRB during 2000-2010. 
Annual total NPP exhibits a slightly increasing trend across the YRB, with an annual rate of change of up to $6 \mathrm{TgCyr}^{-1} \mathrm{yr}^{-1}$. These results indicate that mean annual total NPP was $1076 \mathrm{TgCyr}^{-1}$, with a maximum of $1129 \mathrm{TgCy}^{-1}$ in 2002 (53 $\mathrm{TgCyr}^{-1}$ above the mean) and a minimum of $1009 \mathrm{TgCyr}^{-1}$ in 2000 (67 $\mathrm{TgCyr}^{-1}$ below the mean). Annual total NPP increased from $1009 \mathrm{TgCyr}^{-1}$ in 2000 to $1069 \mathrm{TgCyr}^{-1}$ in 2010 (Figure 15).

The areas with lower values of mean annual GPP are mainly in the semi-arid region of sub-frigid zones in the SRYR, and those with higher values are mostly in the Qinba Mountains and the south-eastern hills (Figure 16a). Like the spatial pattern of the mean value of annual GPP, the areas with lower values of mean annual NPP are mainly distributed in semi-arid and semi-humid areas of the sub-frigid zone in the source regions of Gansu, and in eastern Tibet and eastern Sichuan (Figure 16b).


b

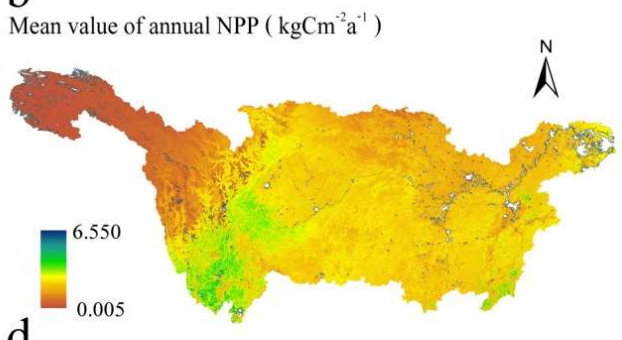

Slope of the linear fitting of annual NPP changes

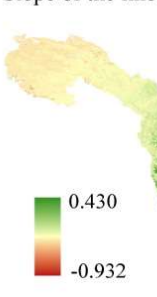

$\AA^{N}$

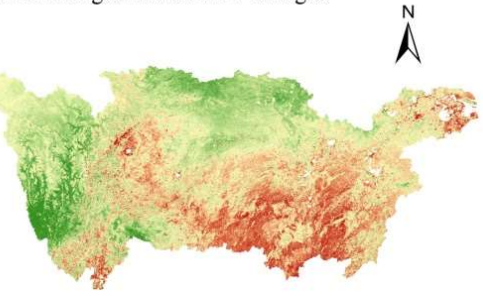

Figure 16. Spatial distribution of (a) the mean values of annual GPP and (b) the mean values of annual NPP; (c) linear trends of annual GPP and (d) linear trends of annual NPP in the YRB during 2000-2010.

The trends in annual GPP and annual NPP show a similar pattern, with an increasing trend in western Sichuan and in the eastern part of Tibet and the Qinba Mountain, and a decreasing trend in the southern hills and the densely urbanized area of the YRD (Figure 16c,d).

\subsection{Correlations between Climatic Variations and Ecological Indicators}

Climate change has a significant impact on ecological indicators [46]. Correlation coefficients (r) between mean air temperature and annual precipitation and the various ecological indicators (annual mean NDVI, growing season mean EVI, annual LAI, annual total GPP, and annual total NPP) were calculated to determine the relationships. The results are presented in Figure 17a-d. The ecological indicators exhibit different responses to the climatic variations. The annual mean NDVI and annual mean air temperature showed a significant positive correlation $\left(R^{2}=0.37, p<0.05\right.$, Figure 17a); while mean growing season air temperature was moderate positive correlation with mean growing season EVI $\left(R^{2}=0.24\right.$, Figure $\left.17 b\right)$; In addition, the annual mean air temperature had significant positive correlations with annual LAI $\left(\mathrm{R}^{2}=0.35, p<0.05\right)$ and annual GPP $\left(\mathrm{R}^{2}=0.37, p<0.05\right.$, Figure $\left.17 \mathrm{c}\right)$; while annual mean air temperature was moderate positive correlation with annual NPP $\left(R^{2}=0.28\right.$, Figure $17 \mathrm{~d}$ ). Moreover, we also used the partial regression to analyze the relationship between air temperature and precipitation (see Appendix A: Table A1), and that supported the conclusion by the linear regression analysis that temperature is more closely related to ecological factors than precipitation over the YRB. 

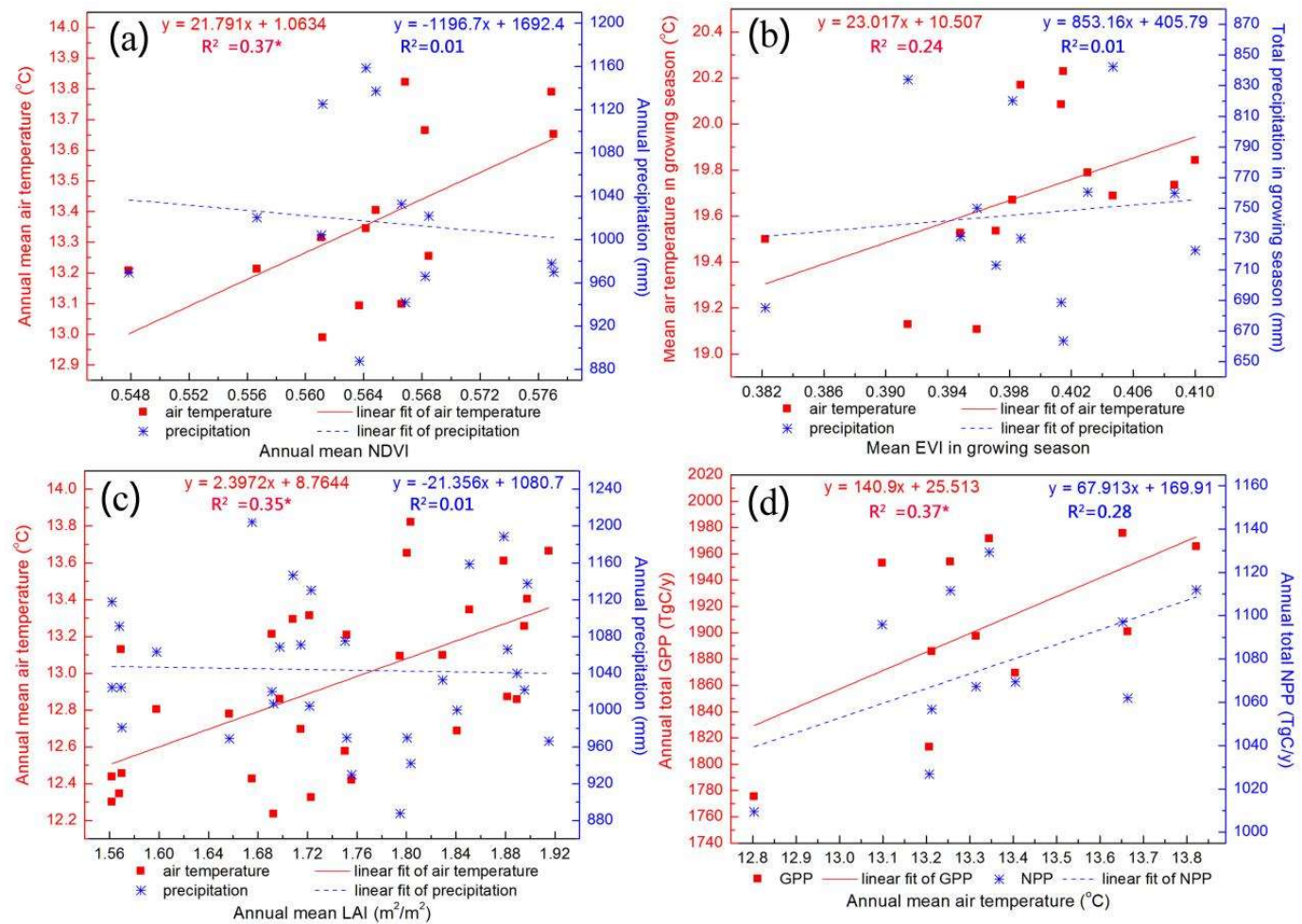

Figure 17. Results of correlation analysis of climatic and ecological parameters for the YRB. (a) Annual mean NDVI and annual mean air temperature/annual precipitation; (b) mean growing season EVI and mean air temperature/total precipitation in the growing season; (c) annual mean LAI and annual mean air temperature/annual precipitation; (d) annual mean air temperature and annual total GPP/NPP. Significance levels: ${ }^{* *}$ means the significant of the $99 \%$ confidence interval, $p<0.01,{ }^{*}$ means the significant of the $95 \%$ confidence interval, $p<0.05$.

\section{Discussion}

Climate change and its impact on terrestrial ecosystems is a major area of concern for global change science. A key aspect is the analysis of spatiotemporal changes in climatic parameters and ecological indicators and their relationships. In this study, we have combined the data outputs from six models from CMIP5 with observed meteorological data to determine the trends, and we have explored the evidence for climate change at local and global levels. In addition, the spatiotemporal trends of various ecological factors were analyzed, and correlation analysis was used to analyze the impact of climate change on the ecological factors. Compared with previous studies, which have tended to focus on a single vegetation index, we have used a variety of vegetation indices and determined their relationship with climate change on different timescales (annual and the growing season) to provide a more comprehensive analysis of the impact of climate change on ecological factors. Lenihan et al. [47] confirmed vital increases in NPP under the warmer and much wetter scenario in California. In a similar study of Hubei Province, in the middles reaches of the YRB, Lin et al. [32] found that increases in GPP, NPP and LAI were significantly correlated with temperature but there was no correlation with precipitation. The absence of a relationship between precipitation and ecological factors may be because there is abundant precipitation in the area and, therefore, water availability is not a limiting factor for vegetation [32]. However, in areas with less rainfall, increases in temperature will result in increased evaporation which may restrict vegetation growth. In the present study we found a positive correlation between NDVI and precipitation for the Tibetan Plateau in the upper reaches of the YRB; in contrast, however, there is a negative correlation between NDVI and temperature [48]. In addition, delta annual EVI (urbanization effects, urban EVIs minus rural EVIs) exhibited a significant decreasing 
trend for nine of the 10 provincial capital cities $(p<0.05)$ in the YRB [49], especially, Shanghai, Nanjing, Hangzhou, etc.

Climate change (including changes in temperature and precipitation, and increases in extreme climate events) and human activities together affect the spatiotemporal variation of ecological indicators [50,51]. Although vegetation changes are usually related to climatic factors, the relationship between vegetation and climate is often unclear in areas that are strongly influenced by humans [52]. For example, in the YRD, despite the significant increasing trend in temperature, ecological factors exhibit a significant decreasing trend (Figures 13, 15 and 17), in accord with the results of Piao et al. [53] who concluded that rapid urbanization has resulted in a sharp decrease in the NDVI over the YRD. The impact of human activities on vegetation generally includes two aspects: direct changes in vegetation resulting from artificial afforestation, deforestation, crop planting or harvesting, and human-induced land-use change; and the other is indirect impacts on vegetation [54-58]. For example, human-induced land use changes and greenhouse gas emissions may cause climate change at the local, regional, and global scales which have further affected vegetation growth and composition [59]. Quantifying the effect of human activities on vegetation is urgently needed, as is also the role of human activities in local vegetation-climate feedbacks. Qu et al. [55] have proposed that over 6\% of the land surface of China has experienced significant human-induced vegetation changes $(p<0.05)$. Mao et al. [52] found that about $97.4 \%$ of the Shanxi-Ganning area showed an increasing trend in vegetation coverage, which was related to China's ecological recovery policy during the last 15 years.

\section{Conclusions}

We have systematically analyzed the spatiotemporal trends of observed and modeled climatic parameters and ecological indicators in the YRB, with the following major conclusions:

Both the observed data and the model results reveal an increasing trend of air temperature in the YRB during 1961-2013; there was a significant increase in temperature across $99.94 \%$ of the region during 1961-2013. However, there is no significant linear trend for annual mean precipitation.

To explore temporal trends in ecological indicators, we analyzed variations in annual NDVI and EVI, LAI, annual total GPP and NPP, which exhibited respective rates of increase of $0.002 \mathrm{yr}^{-1}$, $0.001 \mathrm{yr}^{-1}, 0.07 \mathrm{~m}^{2} \mathrm{~m}^{-2} \mathrm{decade}^{-1}, 9 \mathrm{TgCyr}^{-1} \mathrm{yr}^{-1}$, and $6 \mathrm{TgCyr}^{-1} \mathrm{yr}^{-1}$.

Our results indicated that ecological factors were more strongly correlated with temperature. Specifically, annual mean NDVI and annual mean air temperature showed a significant positive correlation, while the mean growing season air temperature was a moderate positive correlation with mean growing season EVI. In addition, the annual mean air temperature had significant positive correlations with annual LAI and annual GPP; while annual mean air temperature was a moderate positive correlation with annual NPP. So temperature may be the main climatic factor influencing the ecosystem performance over the YRB in the past decades.

Finally, possible deficiencies in our methodology should be considered: because of inherent limitations the meteorological data was selected based on the site data, and the spatial interpolation required may have introduced unavoidable errors. In addition, the differences in ecological response to climate change at the global and regional scales need to be considered. Therefore, in future research, climate change and its impact on ecological factors should be analyzed on different spatial scales.

Author Contributions: F.C. and A.L. designed the research; F.C. and H.Z. performed the experiments and wrote the paper; J.N. corrected and modified the manuscript.

Funding: This research was jointly supported by the National Natural Science Foundation of China (No.41771438, No.41701637 and No.41671405) and the Youth Science Foundation of Xinyang normal university (2016-QN-046).

Conflicts of Interest: The authors declare no conflict of interest. 


\section{Appendix A}

Table A1. Results of partial correlation analysis of the climate parameters and ecological indicators for the YRB.

\begin{tabular}{cccc}
\hline Climate Parameters & Ecological Indicators & $\mathbf{R}^{\mathbf{2}}$ & Sig \\
\hline & Annual mean NDVI & $0.37^{*}$ & 0.037 \\
& Mean EVI in growing season & $0.37^{*}$ & 0.035 \\
Temperature (Controlled Precipitation) & Annual mean LAI & $0.35^{* *}$ & 0.001 \\
& Annual GPP & $0.40^{*}$ & 0.049 \\
& Annual NPP & $0.41 *$ & 0.044 \\
\hline & Annual mean NDVI & 0.01 & 0.776 \\
Precipitation (Controlled Temperature) & Aean EVI in growing season & 0.19 & 0.158 \\
& Annual mean LAI & 0.00 & 0.799 \\
& Annual GPP & 0.06 & 0.491 \\
& Annual NPP & 0.21 & 0.187 \\
\hline
\end{tabular}

Significance levels: ${ }^{* *} p<0.01,{ }^{*} p<0.05$.

\section{References}

1. Gang, C.; Zhang, Y.; Wang, Z.; Chen, Y.; Yang, Y.; Li, J.; Cheng, J.; Qi, J.; Odeh, I. Modeling the dynamics of distribution, extent, and NPP of global terrestrial ecosystems in response to future climate change. Glob. Planet. Chang. 2017, 148, 153-165. [CrossRef]

2. Cao, M.; Woodward, F.L. Dynamic responses of terrestrial ecosystem carbon cycling to global climate change. Nature 1998, 393, 249-252. [CrossRef]

3. Qin, D.; Stocker, T. Highlights of the IPCC Working Group I Fifth Assessment Report. Prog. Inquisitions Mutat. Clim. 2014, 10, 1-6.

4. Zhang, Q.; Zhao, D.; Hong, W.; Dai, E. Research on Vegetation Changes and Influence Factors Based of Eco-geographical Regions of Inner Mongolia. Sci. Geogr. Sin. 2013, 33, 594-601.

5. Yue, T.; Fan, Z. A review of responses of typical terrestrial ecosystems to climate change. Chin. Sci. Bull. 2014, 59, 217-231. [CrossRef]

6. Zhu, Z.; Piao, S.; Myneni, R.B.; Huang, M.; Zeng, Z.; Canadell, J.G.; Ciais, P.; Sitch, S.; Friedlingstein, P.; Arneth, A.; et al. Greening of the Earth and its drivers. Nat. Clim. Chang. 2016, 6, 791-795. [CrossRef]

7. Yuan, Q.; Wu, S.; Dai, E.; Zhao, D.; Ren, P.; Zhang, X. NPP vulnerability of the potential vegetation of China to climate change in the past and future. J. Geogr. Sci. 2017, 27, 131-142. [CrossRef]

8. Piao, S.; Ciais, P.; Huang, Y.; Shen, Z.; Peng, S.; Li, J.; Zhou, L.; Liu, H.; Ma, Y.; Ding, Y.; et al. The impacts of climate change on water resources and agriculture in China. Nature 2010, 467, 43-51. [CrossRef] [PubMed]

9. Reich, P.B.; Sendall, K.M.; Stefanski, A.; Wei, X.; Rich, R.L.; Montgomery, R.A. Boreal and temperate trees show strong acclimation of respiration to warming. Nature 2016, 531, 633-636. [CrossRef] [PubMed]

10. Fang, J.; Piao, S.; Tang, Z.; Peng, C.; Ji, W. Interannual Variability in Net Primary Production and Precipitation Science. Science 2001, 293, 1723. [CrossRef] [PubMed]

11. Behrenfeld, M.J.; Randerson, J.T.; Mcclain, C.R.; Feldman, G.C.; Los, S.O.; Tucker, C.J.; Falkowski, P.G.; Field, C.B.; Frouin, R.; Esaias, W.E. Biospheric Primary Production during an ENSO Transition. Science 2001, 291, 2594-2597. [CrossRef] [PubMed]

12. Running, S.W.; Thornton, P.E.; Nemani, R.; Glassy, J.M. Global Terrestrial Gross and Net Primary Productivity from the Earth Observing System; Springer: New York, NY, USA, 2000.

13. Kleidon, A. The climate sensitivity to human appropriation of vegetation productivity and its thermodynamic characterization. Glob. Planet. Chang. 2006, 54, 109-127. [CrossRef]

14. Spano, D.; Cesaraccio, C.; Duce, P.; Snyder, R.L. Phenological stages of natural species and their use as climate indicators. Int. J. Biometeorol. 1999, 42, 124-133. [CrossRef]

15. Zhang, X.; Friedl, M.A.; Schaaf, C.B.; Strahler, A.H. Climate controls on vegetation phenological patterns in northern mid- and high latitudes inferred from MODIS data. Glob. Chang. Biol. 2004, 10, 1133-1145. [CrossRef] 
16. Munir, T.M.; Perkins, M.; Kaing, E.; Strack, M. Carbon dioxide flux and net primary production of a boreal treed bog: Responses to warming and water table manipulations. Biogeosci. Discuss. 2014, 11, 12937-12983. [CrossRef]

17. Jenny, H. Factors of Soil Formation: A System of Quantitative Pedology; The Maple Press Company: York, PA, USA, 1941.

18. Jenny, H. The Soil Resource-Origin and Behavior. Ecological Studies 37; Springer-Verlag New York, Inc.: New York, NY, USA, 1984.

19. Davidson, E.A.; Janssens, I.A. Temperature sensitivity of soil carbon decomposition and feedbacks to climate change. Nature 2006, 440, 165-173. [CrossRef] [PubMed]

20. Kirschbaum, M.U.F. Will changes in soil organic carbon act as a positive or negative feedback on global warming? Biogeochemistry 2000, 48, 21-51. [CrossRef]

21. Fang, S.; Yan, J.; Che, M.; Zhu, Y.; Liu, Z.; Pei, H.; Zhang, H.; Xu, G.; Lin, X. Climate change and the ecological responses in Xinjiang, China: Model simulations and data analyses. Quat. Int. 2013, 311, 108-116. [CrossRef]

22. Hao, L.; Pan, C.; Liu, P.; Zhou, D.; Zhang, L.; Xiong, Z.; Liu, Y.; Sun, G. Detection of the Coupling between Vegetation Leaf Area and Climate in a Multifunctional Watershed, Northwestern China. Remote Sens. 2016, 8, 1032. [CrossRef]

23. Liang, W.; Yang, Y.; Fan, D.; Guan, H.; Zhang, T.; Long, D.; Zhou, Y.; Bai, D. Analysis of spatial and temporal patterns of net primary production and their climate controls in China from 1982 to 2010. Agric. For. Meteorol. 2015, 204, 22-36. [CrossRef]

24. Huang, K.; Zhang, Y.; Zhu, J.; Liu, Y.; Zu, J.; Zhang, J. The Influences of Climate Change and Human Activities on Vegetation Dynamics in the Qinghai-Tibet Plateau. Remote Sens. 2016, 8, 876. [CrossRef]

25. Zhou, D.; Zhao, S.; Zhang, L.; Liu, S. Remotely sensed assessment of urbanization effects on vegetation phenology in China's 32 major cities. Remote Sens. Environ. 2016, 176, 272-281. [CrossRef]

26. Zhang, Y.; Song, C.; Zhang, K.; Cheng, X.; Band, L.E.; Zhang, Q. Effects of land use/land cover and climate changes on terrestrial net primary productivity in the Yangtze River Basin, China, from 2001 to 2010. J. Geophys. Res. Biogeosci. 2014, 116, 1092-1109. [CrossRef]

27. Qu, S.; Wang, L.; Lin, A.; Zhu, H.; Yuan, M. What drives the vegetation restoration in Yangtze River basin, China: Climate change or anthropogenic factors? Ecol. Indic. 2018, 90, 438-450. [CrossRef]

28. Commission, Y.R.W.R. Atlas of the Yangtze River Basin; The Sino Maps Press: Beijing, China, 1999.

29. Tang, C.; Sun, W. Comprehensive evaluation of land spatial development suitability of the Yangtze River Basin. Acta Geogr. Sin. 2012, 67, 1587-1598.

30. Kai, G.; Zhou, Z.; Yang, Y. Land use structure and its spatial autocorrelation analysis in the Yangtze River Basin. Resour. Environ. Yangtze Basin 2010, 19, 13-20.

31. Ke, J.; Piao, S.; Fang, J. NPP and its spatiotemporal Patterns in the Yangtze River Watershed. Acta Phytoecol. Sin. 2003, 27, 764-770.

32. Lin, A.; Zhu, H.; Wang, L.; Gong, W.; Zou, L. Characteristics of Long-Term Climate Change and the Ecological Responses in Central China. Earth Interact. 2016, 20, 1-24. [CrossRef]

33. Pan, Z.; Zhang, Y.; Liu, X.; Gao, Z. Current and future precipitation extremes over Mississippi and Yangtze River basins as simulated in CMIP5 models. J. Earth Sci. China 2016, 27, 22-36. [CrossRef]

34. Kimball, J.S.; Zhao, M.; Mcguire, A.D.; Heinsch, F.A.; Clein, J.; Calef, M.; Jolly, W.M.; Kang, S.; Euskirchen, S.E.; Mcdonald, K.C. Recent Climate-Driven Increases in Vegetation Productivity for the Western Arctic: Evidence of an Acceleration of the Northern Terrestrial Carbon Cycle. Earth Interact. 2007, 11, 4. [CrossRef]

35. Zhu, Z.; Bi, J.; Pan, Y.; Ganguly, S.; Anav, A.; Xu, L.; Samanta, A.; Piao, S.; Nemani, R.; Myneni, R. Global Data Sets of Vegetation Leaf Area Index (LAI)3g and Fraction of Photosynthetically Active Radiation (FPAR) $3 \mathrm{~g}$ Derived from Global Inventory Modeling and Mapping Studies (GIMMS) Normalized Difference Vegetation Index (NDVI3g) for the Period 1981 to 2011. Remote Sens. 2013, 5, 927-948.

36. Brassel, K.E.; Reif, D. A Procedure to Generate Thiessen Polygons. Geogr. Anal. 1979, 11, 289-303. [CrossRef]

37. Powell, M.J.D. Radial basis functions for multivariable interpolation: A review. In Algorithms for Approximation; Clarendon Press: New York, NY, USA, 1987; pp. 143-167.

38. Oliver, M.; Webster, R. Kriging: A method of interpolation for geographical information systems. Int. J. Geogr. Inf. Syst. 1990, 4, 313-332. [CrossRef]

39. Lu, G.Y.; Wong, D.W. An adaptive inverse-distance weighting spatial interpolation technique. Comput. Geosci. 2008, 34, 1044-1055. [CrossRef] 
40. Krajewski, W.F. Co-Kriging of Radar-Rainfall and Rain Gauge Data. J. Geophys. Res. Atmos. 1987, 92, 9571-9580. [CrossRef]

41. Del, G.S.; Parton, W.; Stohlgren, T.; Zheng, D.; Bachelet, D.; Prince, S.; Hibbard, K.; Olson, R. Global potential net primary production predicted from vegetation class, precipitation, and temperature. Ecology 2008, 89, 2117-2126.

42. ConG, N.; Shen, M.; Piao, S. Spatial variations in responses of vegetation autumn phenology to climate change on the Tibetan Plateau. J. Plant Ecol. 2017, 10, 744-752. [CrossRef]

43. Chatfield, C. The analysis of time series: An introduction/C. Chatfield. Technometrics 1991, 33, 363-364.

44. Wang, Q.; Zhang, M.; Wang, S. Extreme temperature events in Yangtze River Basin during 1962-2011. J. Geogr. Sci. 2014, 24, 59-75. [CrossRef]

45. Fasano, G.; Franceschini, A. A multidimensional version of the Kolmogorov-Smirnov test. Mon. Not. R. Astron. Soc. 1987, 225, 9-20. [CrossRef]

46. Zhao, A.; Zhang, A.; Liu, X.; Cao, S. Spatiotemporal changes of normalized difference vegetation index (NDVI) and response to climate extremes and ecological restoration in the Loess Plateau, China. Theor. Appl. Climatol. 2018, 132, 555-567. [CrossRef]

47. Lenihan, J.M.; Bachelet, D.; Neilson, R.P.; Drapek, R. Response of vegetation distribution, ecosystem productivity, and fire to climate change scenarios for California. Clim. Chang. 2008, 87, 215-230. [CrossRef]

48. An, C.; Fan, J.; Zhang, Y.; Yan, D. Characterizing the responses of vegetation to climate change in the Tibet Plateau using remote sensing data. J. Appl. Remote Sens. 2018, 12, 016035. [CrossRef]

49. Yao, R.; Wang, L.; Gui, X.; Zheng, Y.; Zhang, H.; Huang, X. Urbanization Effects on Vegetation and Surface Urban Heat Islands in China's Yangtze River Basin. Remote Sens. 2017, 9, 540. [CrossRef]

50. Kazak, J. The Use of a Decision Support System for Sustainable Urbanization and Thermal Comfort in Adaptation to Climate Change Actions-The Case of the Wrocław Larger Urban Zone (Poland). Sustainability 2018, 10, 1083. [CrossRef]

51. Sun, Y.; Yang, Y.; Zhang, L.; Wang, Z. The relative roles of climate variations and human activities in vegetation change in North China. Phys. Chem. Earth Parts A/B/C 2015, 87-88, 67-78. [CrossRef]

52. Miao, L.; Liu, Q.; Fraser, R.; He, B.; Cui, X. Shifts in vegetation growth in response to multiple factors on the Mongolian Plateau from 1982 to 2011. Phys. Chem. Earth Parts A/B/C 2015, 87-88, 50-59. [CrossRef]

53. Piao, S.; Mohammat, A.; Fang, J.; Cai, Q.; Feng, J. NDVI-based increase in growth of temperate grasslands and its responses to climate changes in China. Glob. Environ. Chang. 2006, 16, 340-348. [CrossRef]

54. Jiang, L.; Jiapaer, G.; Bao, A.; Guo, H.; Ndayisaba, F. Vegetation dynamics and responses to climate change and human activities in Central Asia. Sci. Total Environ. 2017, 599-600, 967-980. [CrossRef] [PubMed]

55. Qu, B.; Zhu, W.; Jia, S.; Lv, A. Spatio-Temporal Changes in Vegetation Activity and Its Driving Factors during the Growing Season in China from 1982 to 2011. Remote Sens. 2015, 7, 13729-13752. [CrossRef]

56. Tong, S.; Zhang, J.; Bao, Y.; Lai, Q.; Xiao, L.; Li, N.; Bao, Y. Analyzing vegetation dynamic trend on the Mongolian Plateau based on the Hurst exponent and influencing factors from 1982-2013. J. Geogr. Sci. 2018, 28, 595-610. [CrossRef]

57. Wang, J.; Wang, K.; Zhang, M.; Zhang, C. Impacts of climate change and human activities on vegetation cover in hilly southern China. Ecol. Eng. 2015, 81, 451-461. [CrossRef]

58. Wen, Z.; Wu, S.; Chen, J.; Lü, M. NDVI indicated long-term interannual changes in vegetation activities and their responses to climatic and anthropogenic factors in the Three Gorges Reservoir Region, China. Sci. Total Environ. 2017, 574, 947-959. [CrossRef] [PubMed]

59. Li, S.; Yang, S.; Liu, X.; Liu, Y.; Shi, M. NDVI-Based Analysis on the Influence of Climate Change and Human Activities on Vegetation Restoration in the Shaanxi-Gansu-Ningxia Region, Central China. Remote Sens. 2015, 7, 11163-11182. [CrossRef]

(C) 2018 by the authors. Licensee MDPI, Basel, Switzerland. This article is an open access article distributed under the terms and conditions of the Creative Commons Attribution (CC BY) license (http:/ / creativecommons.org/licenses/by/4.0/). 